Bull. Fac.Agric., Cairo Univ., 68: 105-117 (2017).

\title{
EFFECTIVENESS OF NON-GOVERNMENTAL ORGANIZATIONS IN DEVELOPING THE ENVIRONMENTAL AWARENESS IN RURAL AREAS OF GIZA GOVERNORATE
}

\author{
(Received: 27.7.2017)
}

\author{
By \\ M. Y. A. Radwan \\ Department of Rural Sociology, Faculty of Agriculture, Al-Azhar University, Cairo, Egypt
}

\begin{abstract}
The present research aimed mainly to determine the degree of effectiveness of NGOs in developing the environmental awareness of rural areas through the following objectives: determining knowledge degree of rural respondents about NGOs activities in the field of environmental awareness development, their performance degree of these activities, the benefits degree of respondents from these activities, respondents satisfaction with these activities, determining the significant relationship between the studied independent variables and the effectiveness degree of NGOs in performing their activities, recognizing the important problems facing these organizations and their suggestions to eliminate these problems. This research was conducted on 150 respondents as beneficiaries from these NGOs besides 50 from boards of directors of the studied organizations. Data were collected through two questionnaires during January 2017; after that, data have been discharged and analyzed statistically; tables, percentage, simple correlation coefficient, Chi square, and average degree were used in the presentation and analysis of results. It was clear from the results that: the highest percentage of respondents fall in the medium level of knowledge category. The highest percentage of respondents fall in the medium level of performance category. The highest percentage of respondents fall in the medium level of benefit category. The effectiveness level of the organizations about their performance was medium. There was a significant relationship at the level of 0.01 between the age variable and the effectiveness of the organizations in the performance of their activities. The most important problem facing these organizations from the perspective of rural respondents was: the lack of bulletins and leaflets to tell rural people about their activities. The most important proposal to overcome these problems from the perspective of rural respondents was: providing bulletins and leaflets to tell rural people about their activities. The most important problem facing these organizations from the perspective of the members of the boards of directors was: lack of sufficient funding, and that the most important proposals from the perspective of the members of the boards of directors was: providing sufficient funding.
\end{abstract}

Key words: non-governmental organizations, environmental awareness, rural areas, Giza governorate.

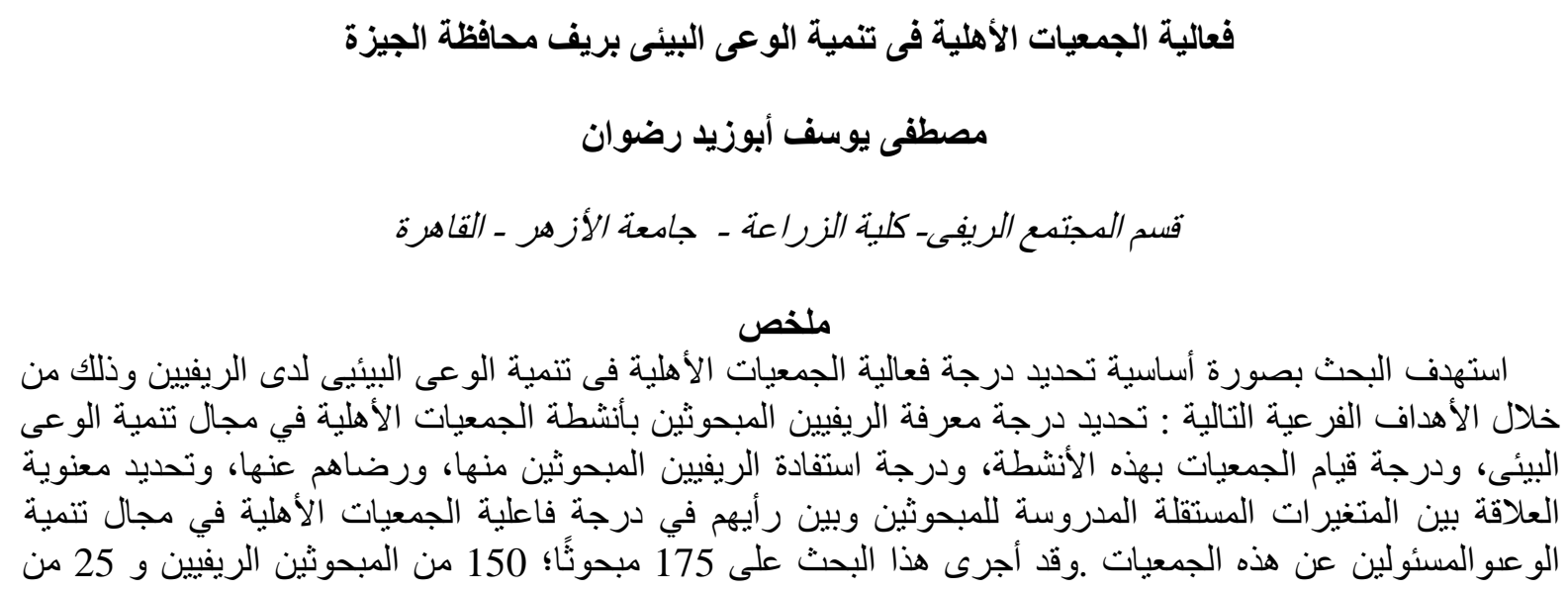


أعضاء مجلس الإدارة بقرى العينة، وتم جمع البيانات الميدانية خلال شهر يناير 2017 من خلال استمارتى استبيان، وبعد

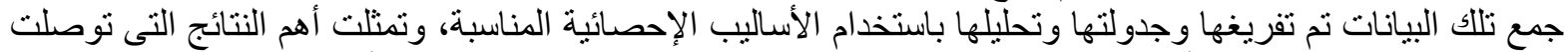

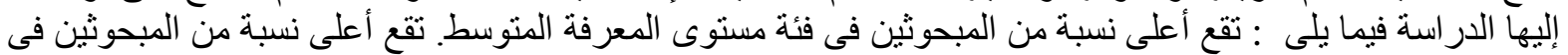

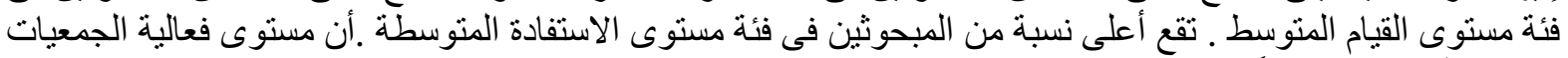

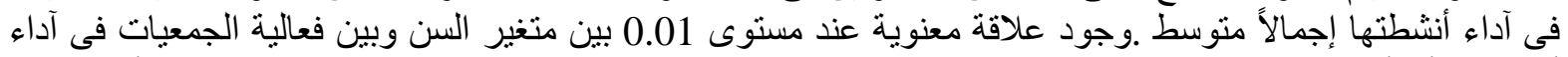

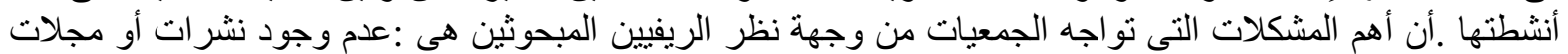

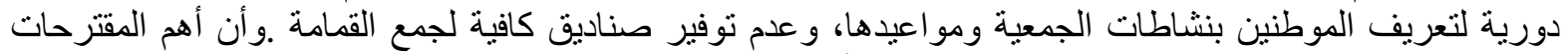

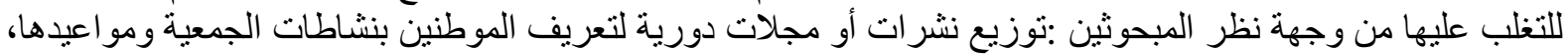

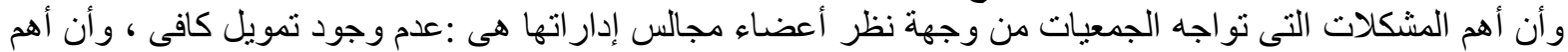

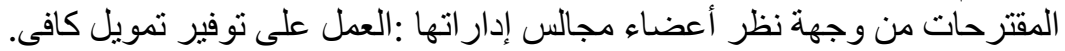

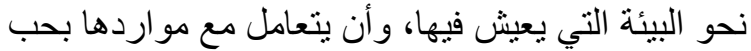

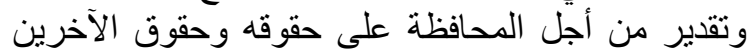

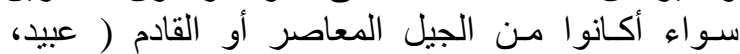
2000). وبذلك فإن التربية البيئية عملية من شأنها أن الن النائ

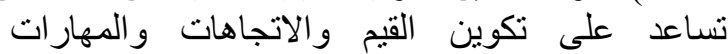
و المعارف، وفهم العلاقات المعقدة التي تربط الإني الإنسان

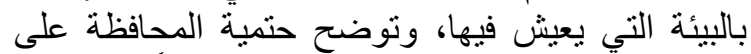

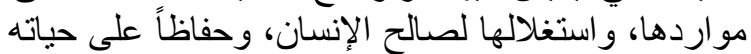

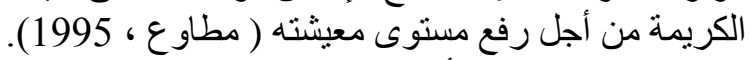

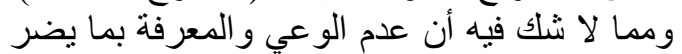

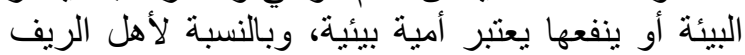

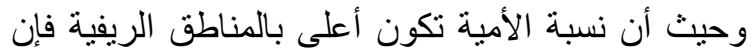

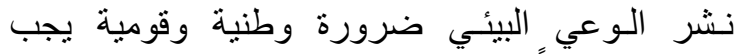

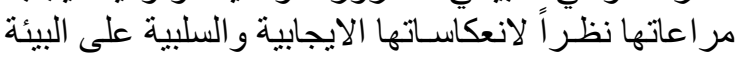

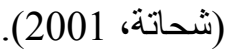

ومن هنا فإن تنمية الوعي البيئي لدى الريفيين بعد في التئي

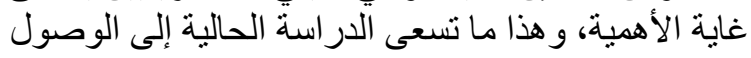

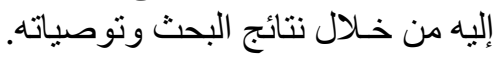

\section{2.مثكلة البحث}

تعرض المجتمع الريفي فى الآونة الأخيرة إلى العديد التيد

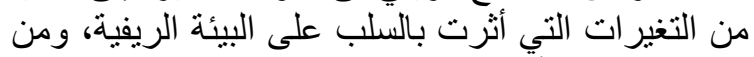

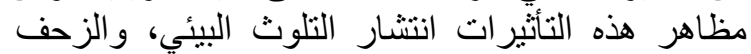

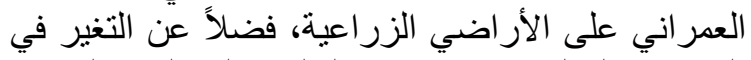

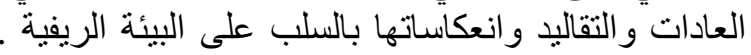

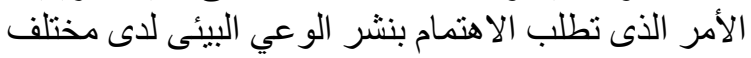

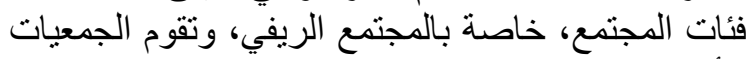

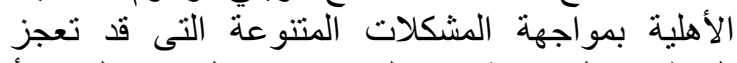

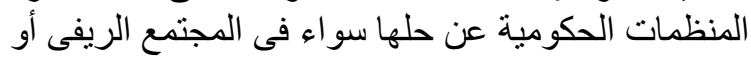

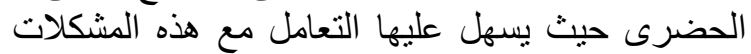
بطريقة مباشرة وسريعة و عن قرب ومن ثم تم تقدم خدماتها

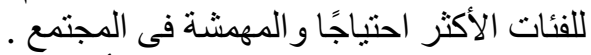

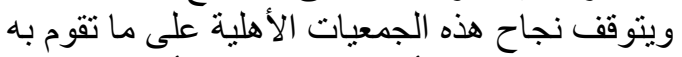

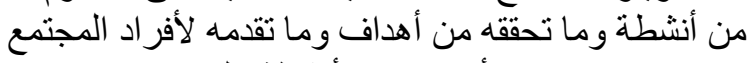

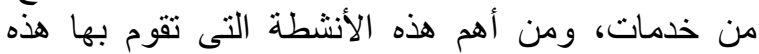

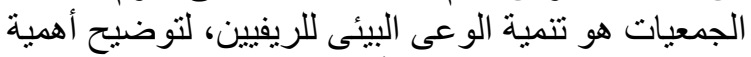

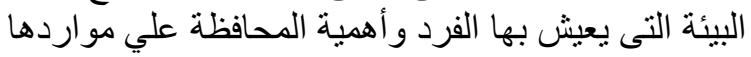

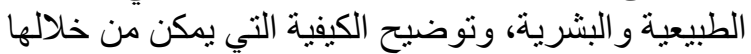

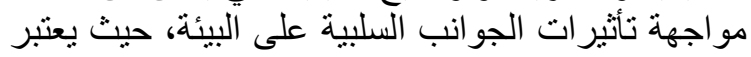

\section{1 المقدمة}

تمثل الأرض البيئة التي تعيش عليها الكائنات الحية

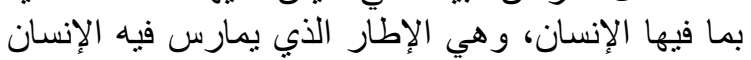

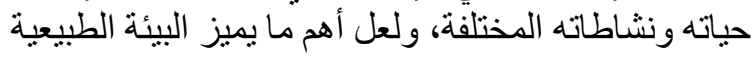

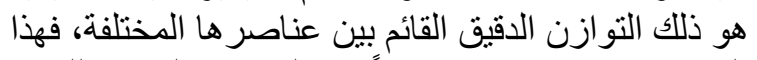

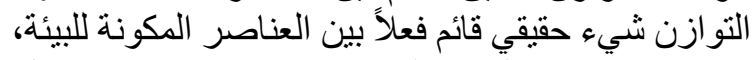

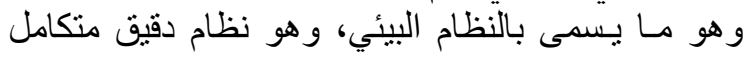
يعيش فيه كل المساهمين في توازئ الإن تام، ويعتبر الإنسان

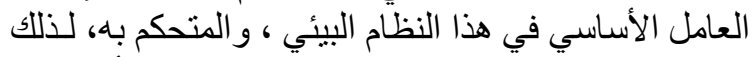

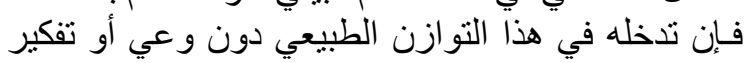

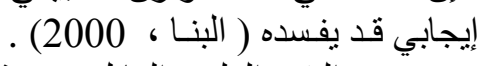
وومع التقدم العلمي الهائل في هذا العصر الذي الذي يتميز

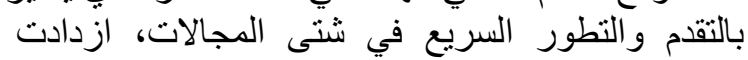

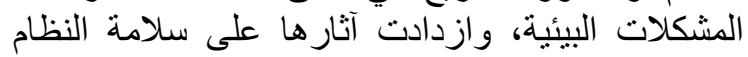

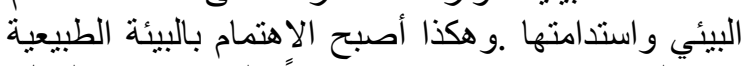

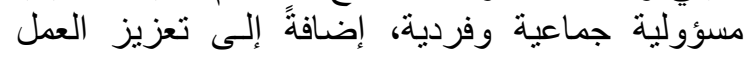

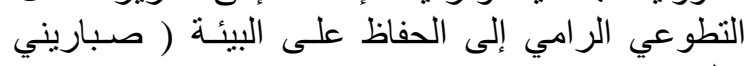
والحمد، 1994 ) ). لقد مرت العلاقة بين الإنسان و البيئة عبر تاريخ

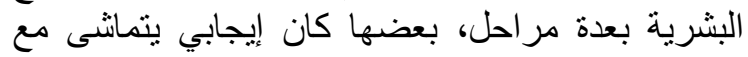

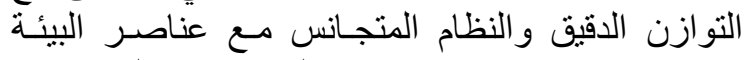

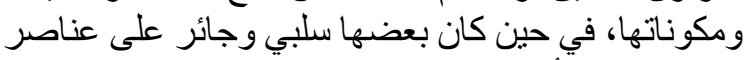

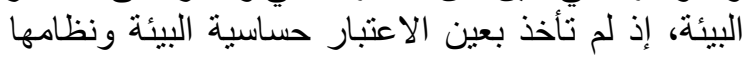

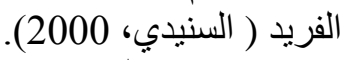
ومما لا شك فيه فإن الإنسان هو المحور الرئبيسي

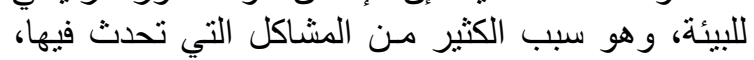

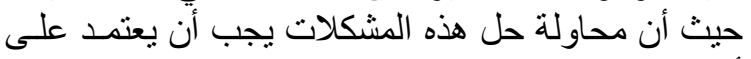

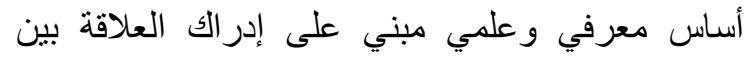

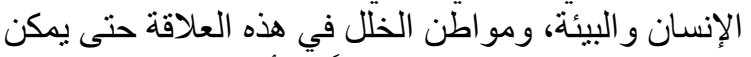

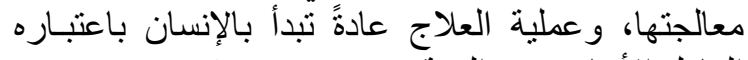

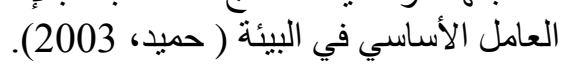

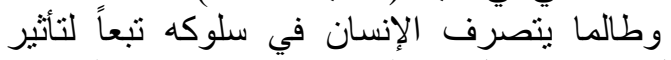

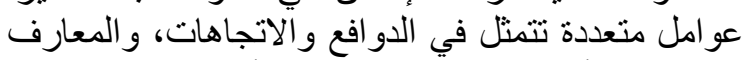

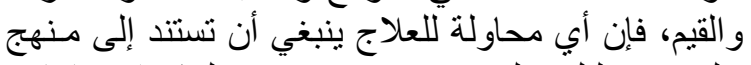

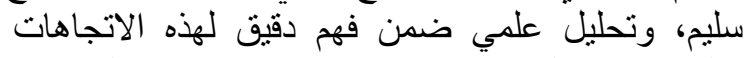

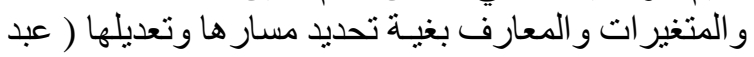
اللطيف، والنغيرات 1998 ).

فالإنسان في جميع مر احل حياته بحاجة إلى التربية

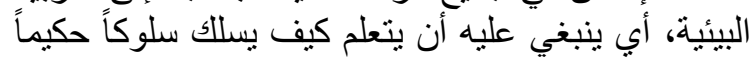


بين المتغيرات المستقلة المدروسة للمبحوثين وهى السن، و وعدد أفراد الأسرة، والحالة الزواجية العية، والحالة والة التعليمية، والمهنة، وجود مشروع صغير والاير وبين رأيهم في درجة الزية فاعلية الجمعيات الأهلية في آداء أنشطتها ".

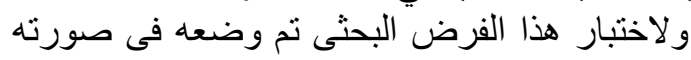
الصفرية.

\section{4.الطريقة البحثية}

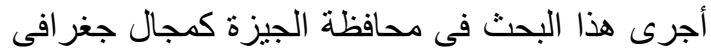

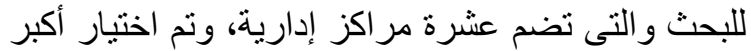

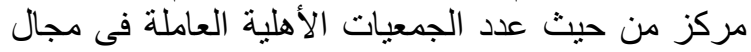

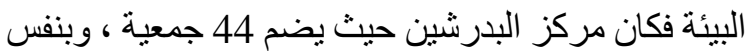

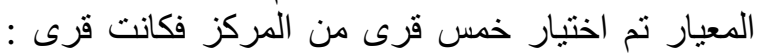

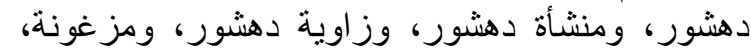

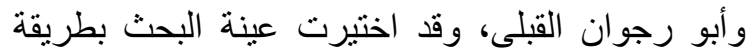
عشو ائية من الريفيين بقرى الدراسة، حيث تمثئ تم اختيار 30

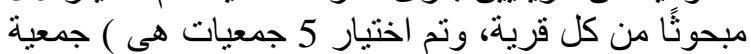

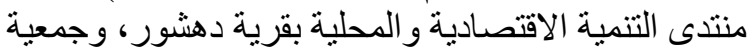

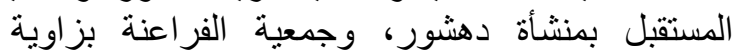

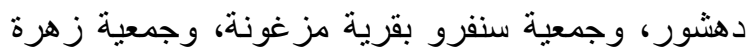

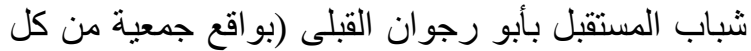

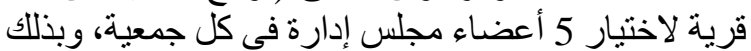

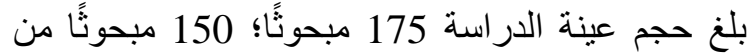
المبحوثين الريفيين و 25 من أعضاء مجلس الإدارة، وتم

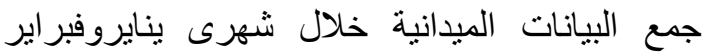
2017من خلال استمارنى استبيان تم تصنيان تصميمهيا

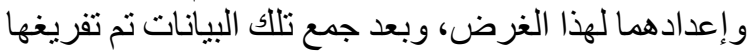

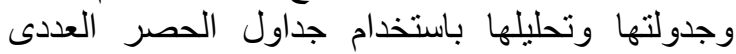

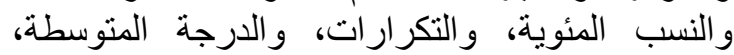

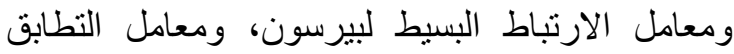

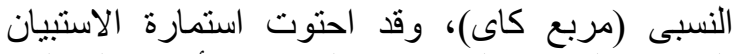
الخاصة بالريفيين المبحوثين على خمسة أقسام على النحو التئي

1.4.القسم الأول : واختص ببعض الصفات الثخصية

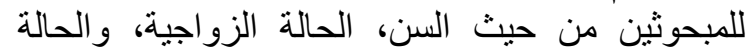

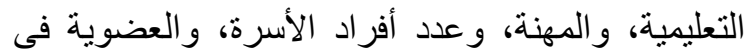
المنظمات الاجتماعية، ومصادر المعرفة بالجمعية، وجود الإدية

مشروع صغير. 2.4.القسم الثانى :واشتمل على الأنشطة التى تقوم بها

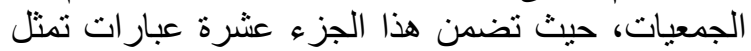

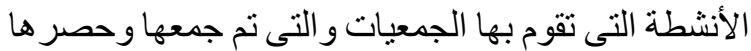

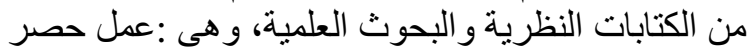

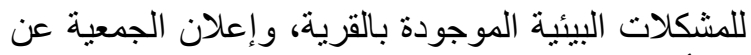

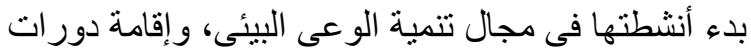

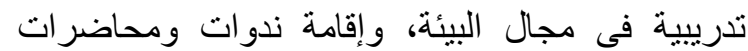

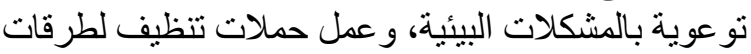

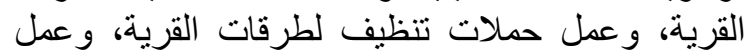
حملات تشجير بالقرية، وتنظيم مسابقات في مجية مجال البيئة،

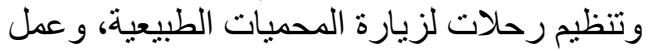

انخفاض الوعى البيئى من أخطر وأهم المشكلات التى التى

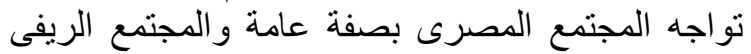
بصفة خاصة. وتعتبر محافظة الجيزة من المحافظات التى ترتفع من

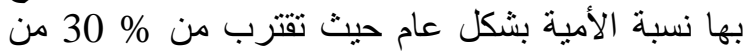

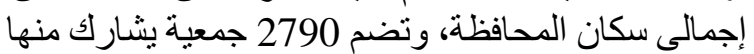

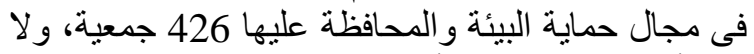
شك أن ارتفاع نسبة الأمية سوف يترتب التب عليه عليه انخفاض

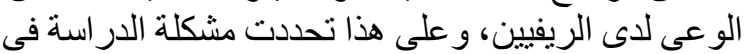

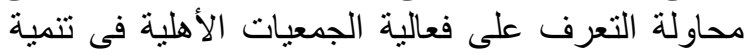

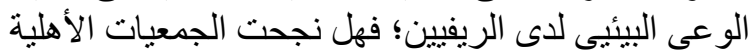

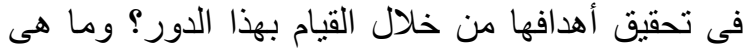
درجة معرفة الريفيين المبحوثين بأنشطة الجمعيات الأهلية

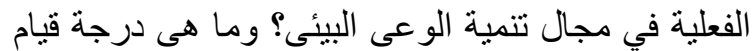

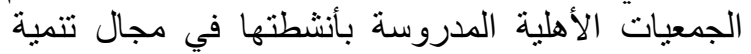

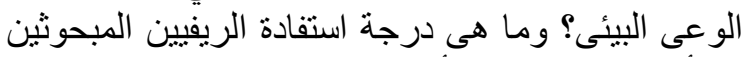

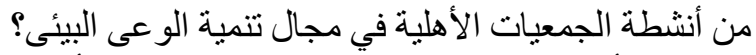

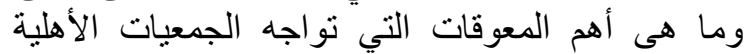

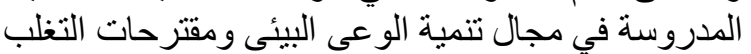

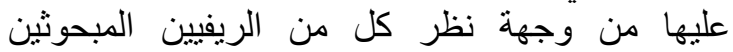
المستفيدين وكذلك المسئولين عن هذه الجمعيات؟

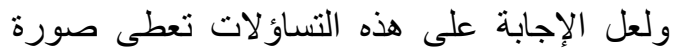

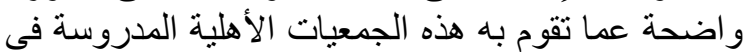

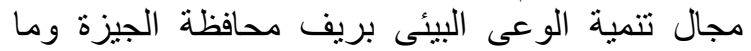

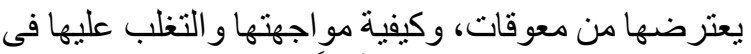

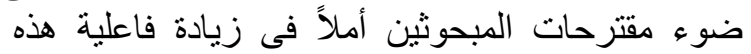
الجمعيات فى القيام بدور ها فى هذا المجال.

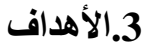

* تحديد درجة معرفة الريفيين المبحوثين بأنشطة الجمعيات الأهلية في مجال تنمية الوعى البين البيئى.

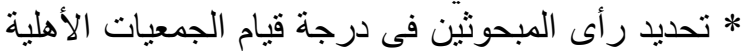

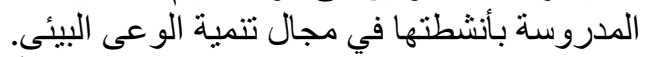

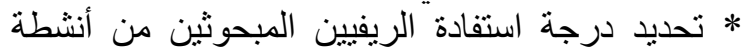

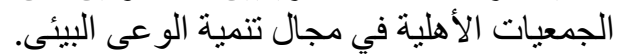

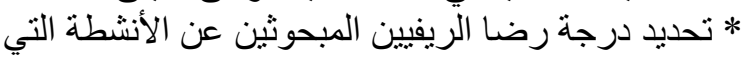

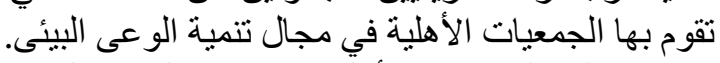

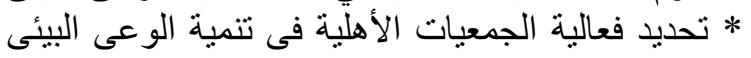
للاريفيين المبحوثين. * التعرف علي أهم المعوقات التي تو اجه الجمعيات الأهلية

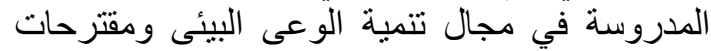

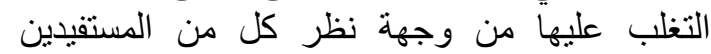
و المسئولين عن هذه الجمعيات. * تحديد معنوية العلاقة بين المتغير الجين التين المستقلة المدروسة

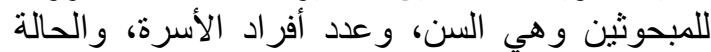

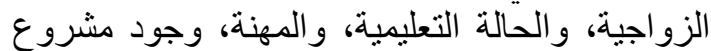
صغير وبين رأيهم في درجة فاعلية الجمعيات الأهلية في مجال تنمية الوعى البيئي. 1.3.الفروض البحثية

نم صياغة فرض بحثى واحد هو " توجد علاقة معنوية 


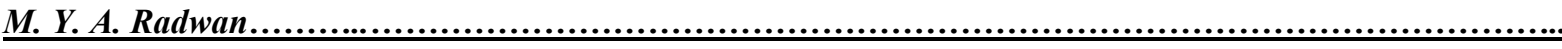

جدول ( 2 ) : توزيع الجمعيات الأهلية العاملة فى مجال البيئة على قرى مركز البدرشين

\begin{tabular}{|c|c|c|}
\hline عدد الجمعيات & القرية & 5 \\
\hline $8 *$ & دهثور & 1 \\
\hline $6 *$ & منشأة دشور & 2 \\
\hline $5 *$ & زاوية دهشور & 3 \\
\hline $4 *$ & مزغونة & 4 \\
\hline $4 *$ & أبو رجوان القبلى & 5 \\
\hline 3 & أبو صير & 6 \\
\hline 2 & أبو رجوان & 7 \\
\hline 2 & الشوبك الغربى & 8 \\
\hline 2 & المرازيق & 9 \\
\hline 2 & العزيزية & 10 \\
\hline 2 & صقارة & 11 \\
\hline 2 & منشأة كاسب & 12 \\
\hline 1 & الشنباب & 13 \\
\hline 1 & ميت رهينة & 14 \\
\hline- & الطرفاية & 15 \\
\hline- & زهران & 16 \\
\hline - & قلعة المرازيق & 17 \\
\hline - & نزلة الشوبك & 18 \\
\hline 44 & 18 قرية & إجمالح \\
\hline
\end{tabular}

2016. المصدر :وزارة التضامن الاجتماعى،

جدول ( 4 ) : أسماء الجمعيات الأهلية العاملة فى مجال البيئة

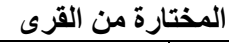

\begin{tabular}{|c|c|c|}
\hline اسم الجمعية & القرية & p \\
\hline جمعية منتدى التنمية & لد دشور & 1 \\
\hline جمعية المستقبل لتنمية المجتمع & منشأة & 2 \\
\hline جمعية الفراعنة للتنمية & زاوية & 3 \\
\hline جمعية سنفرو للتنمية البيئية & مزغونة & 4 \\
\hline جمعية زهرة شباب المستقبل & $\begin{aligned} \text { أبو رجوان } \\
\text { القبلى }\end{aligned}$ & 5 \\
\hline 5 جمعيات & 5 قرى & 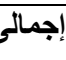 \\
\hline
\end{tabular}

جدول( 1 ) : توزيع الجمعيات العاملة فى مجال البيئة على ألى مراكز وأحياء محافظة الجيزة

\begin{tabular}{|c|c|c|}
\hline عدد الجمعيات & المركز & م \\
\hline $44 *$ & البارشين & 1 \\
\hline 39 & أوسيم & 2 \\
\hline 34 & الدقى & 3 \\
\hline 32 & الأهر ام & 4 \\
\hline 28 & بولاق & 5 \\
\hline 27 & إمبابة & 6 \\
\hline 25 & العجوزة & 7 \\
\hline 25 & الجيزة & 8 \\
\hline 24 & قسم أول 6أكتوبر & 9 \\
\hline 23 & أطفيح & 10 \\
\hline 22 & العياط & 11 \\
\hline 20 & أبو النمرس & 12 \\
\hline 17 & العمر انية & 13 \\
\hline 15 & الصف & 14 \\
\hline 15 & الوراق & 15 \\
\hline 13 & الحوامدية & 16 \\
\hline 11 & كرداسة & 17 \\
\hline 8 & قتسم ثان 6 6أكتوبر & 18 \\
\hline 4 & الواحات البحرية & 19 \\
\hline 426 & 19مركز وحى & إجمالح \\
\hline
\end{tabular}

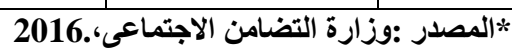

جدول ( 3 ) : توزيع الجمعيات الأهلية العاملة فى مجال البيئة على القرى المختارة

\begin{tabular}{|c|c|c|}
\hline عدد الجمعيات & الّريـة & م \\
\hline 8 & دهشور & 1 \\
\hline 6 & منشأة دشور & 2 \\
\hline 5 & زاوية دهشور & 3 \\
\hline 4 & مزغونة & 4 \\
\hline 4 & أبو رجوان القبلى & 5 \\
\hline 27 & 5قرى & إجمالى \\
\hline
\end{tabular}

المصدر :وزارة التضامن الاجتماعى،2016 


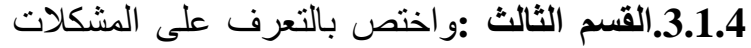

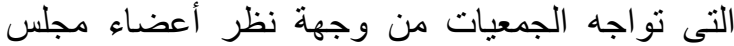

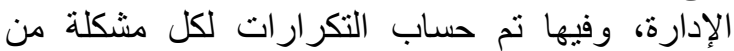

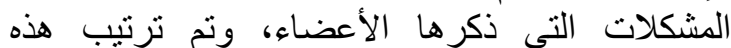

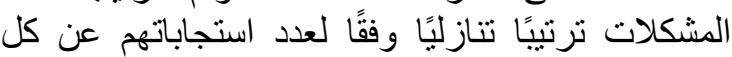
مشكلة

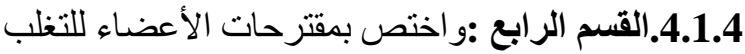

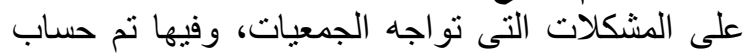

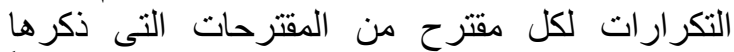

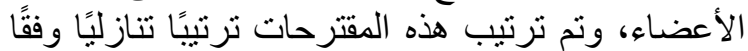

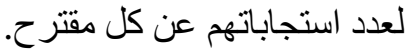

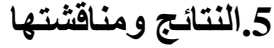

1.5. وصف عينة المبحوثين المستفيدين من الجمعيات:

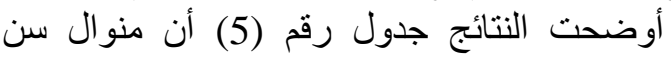

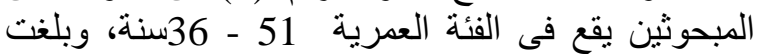

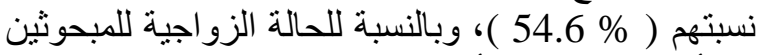

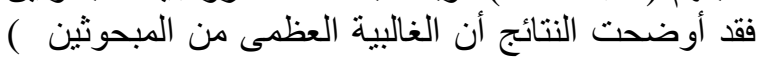

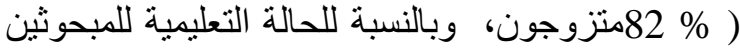
تبين من النتائج تقارب نسبتى المبحوثين في فئتى الحالة

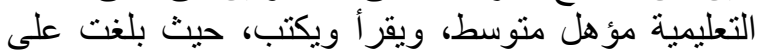

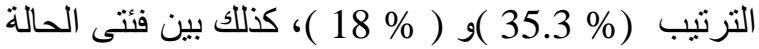

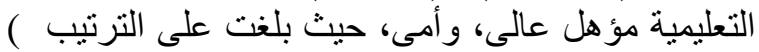

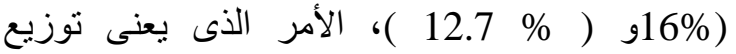
المبحوثين بنسب مختلفة على جميع فئات الحالة التعليمية

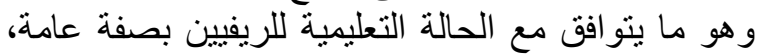

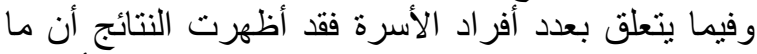

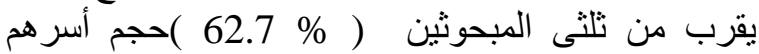

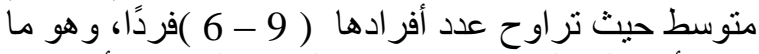
يعنى أنه على الرغم من حملات التو عية لتنظيم الأسرة إلا

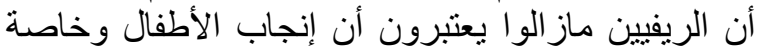

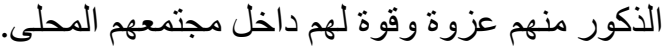

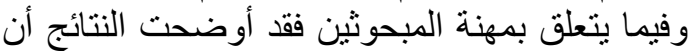
ما يقرب من خمسى المبحوثين (

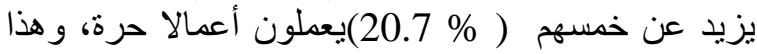

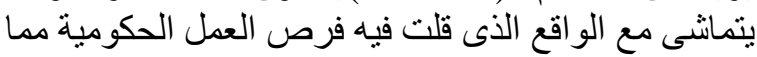

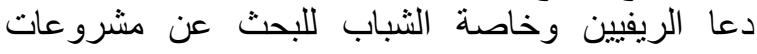

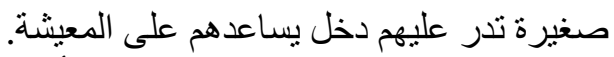

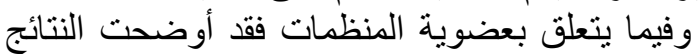
أن ما يزيد عن ثلاثة أرباع المبحوثين (\% 78.7 )يقعون

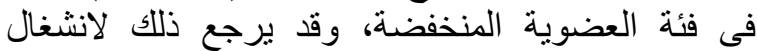

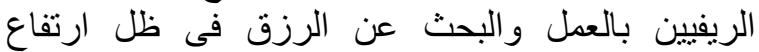

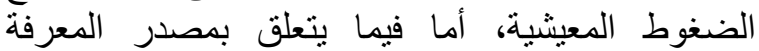

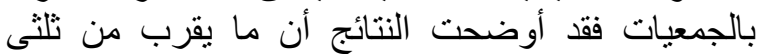

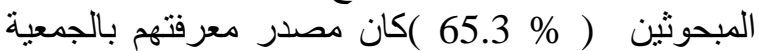

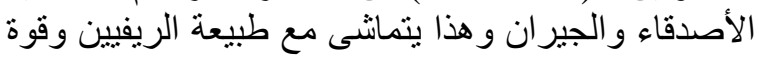

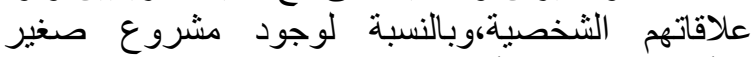

فقدأوضحت النتائج أن غالبية المبحوثين ( 84.7 ) لا لانية

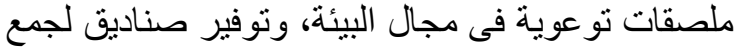
القمامة، وتم قياس معرفة المبحوثين بهذه فئه الأنشطة، وذلكي

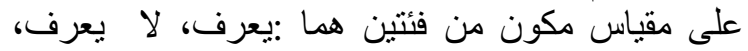

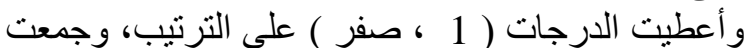

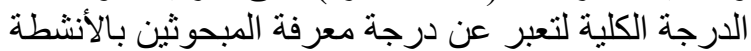

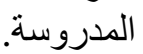
كما اشتنمل هذا الجزء على بلى درجة قيام الجمعيات

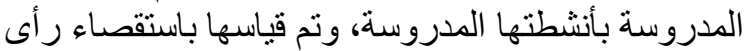

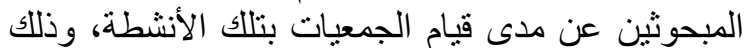

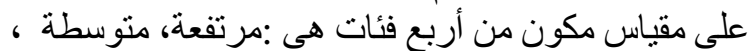

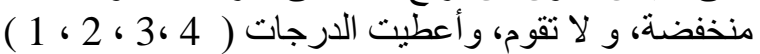
على الترتيب، وجمعت الدرجة الكلية لتعبر عن درجة التهات القيام بتلك الأنشطة المدروسة. 3.4.القسم الثالث :اشتمل هذا الجزء على على درجة استفادة المبحوثين من الأنشطة التى تقدمها الجمعيات، ولثئ وتم قياسها

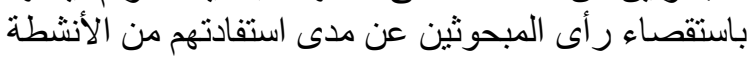

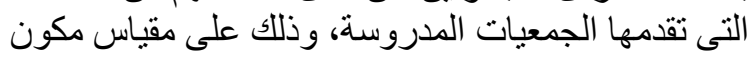

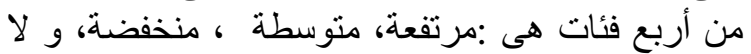

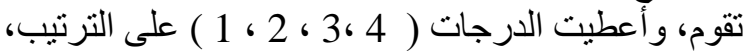
وجمعت الدرجة الكلية لتعبر عن درجة الاستفادة من تلك الكي الأنشطة

كما اشتمل هذا الجزء على درجة رضا المبحوثين عن

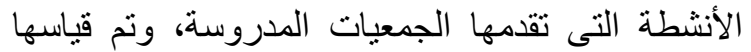

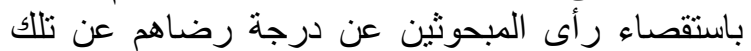

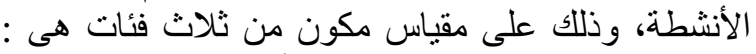

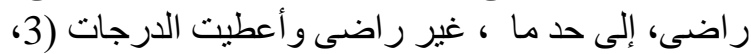

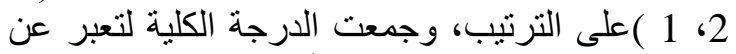

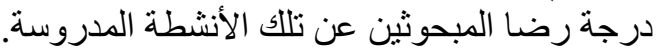
4.4.القسم الرابع :و اختص بالتعرف على على المشكلات التى التى

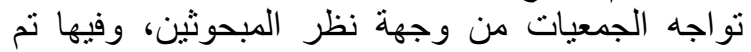

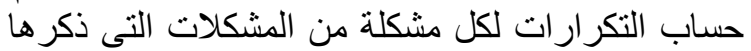

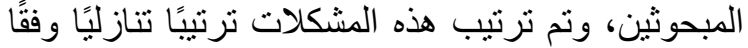

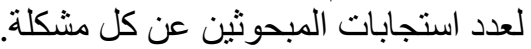
5.4.القسم الخامس :و اختص بمقترحات المبن المبحوثين للتغلب

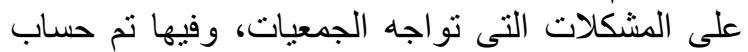

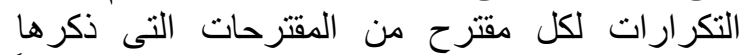

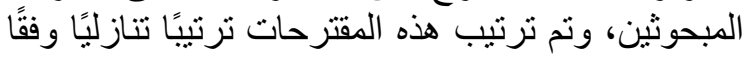

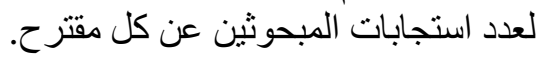

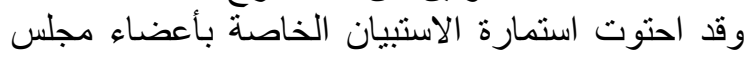
الإدارة على خمسة أقسام على الآنق النحو النتالى:

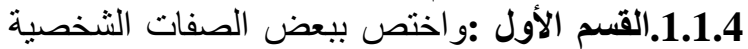

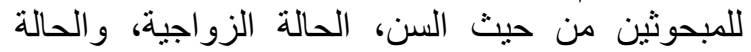

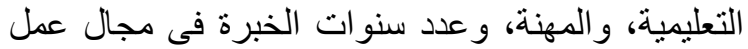

الجمعية، و الحصول على دور العهية وعلد ات تدريبية.

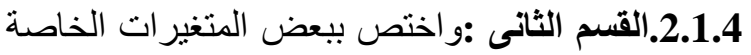

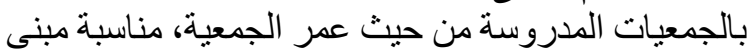

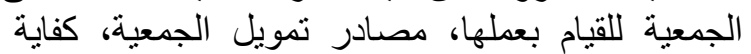
التمويل، كفاية الإمكانيات البشرية، العلاقة بالأجهزة

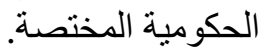




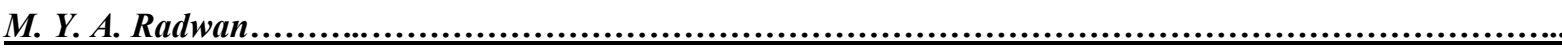

جدول (5) : توزيع الريفيين المبحوثين وفقًا لمتغيراتهم

\begin{tabular}{|c|c|c|c|c|c|}
\hline$\%$ & عدد & متغيرات المبحوثين & $\%$ & عدد & متغيرات المبحوثين \\
\hline $\begin{array}{r}39.3 \\
17.4 \\
13.3 \\
20.7 \\
5.3 \\
4\end{array}$ & $\begin{array}{r}59 \\
26 \\
20 \\
31 \\
8 \\
6\end{array}$ & 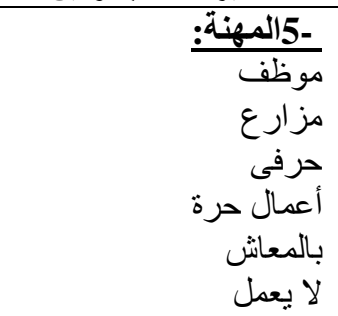 & $\begin{array}{l}28.6 \\
54.6 \\
16.6\end{array}$ & $\begin{array}{l}43 \\
82 \\
25\end{array}$ & 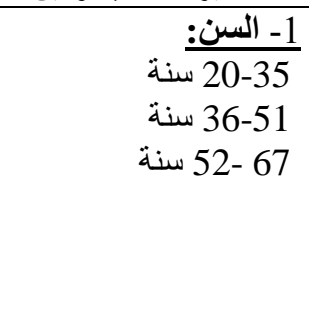 \\
\hline 100 & 150 & المجموع . & 100 & 150 & المجموع . \\
\hline $\begin{array}{r}78.7 \\
18 \\
3.3\end{array}$ & $\begin{array}{r}118 \\
27 \\
5\end{array}$ & 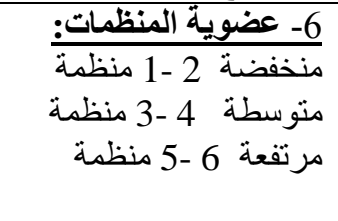 & $\begin{array}{r}11.3 \\
82 \\
4.7 \\
2\end{array}$ & $\begin{array}{r}17 \\
123 \\
7 \\
3\end{array}$ & 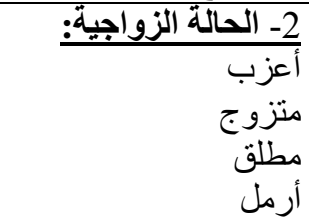 \\
\hline 100 & 150 & المجموع & 100 & 150 & المجموع \\
\hline $\begin{array}{c}65.3 \\
32.7 \\
2\end{array}$ & $\begin{array}{c}98 \\
49 \\
3\end{array}$ & 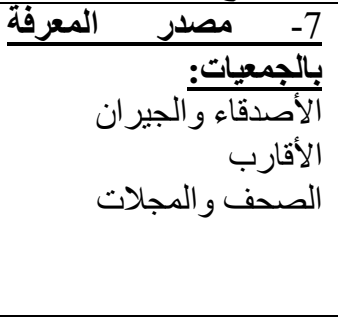 & $\begin{array}{r}12.7 \\
18 \\
6 \\
12 \\
35.3 \\
16\end{array}$ & $\begin{array}{r}19 \\
27 \\
9 \\
18 \\
53 \\
24\end{array}$ & 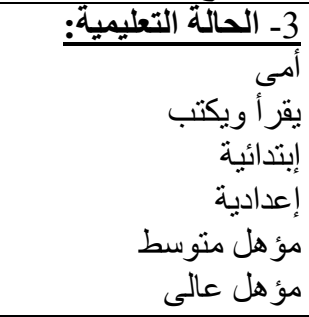 \\
\hline 100 & 150 & المجموع & 100 & 150 & المجموع \\
\hline $\begin{array}{c}84.7 \\
11.3 \\
2.7 \\
1.3 \\
\end{array}$ & $\begin{array}{r}127 \\
17 \\
4 \\
2\end{array}$ & 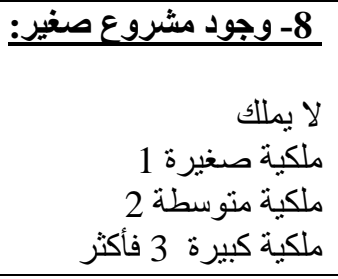 & $\begin{array}{r}24 \\
62.7 \\
13.3\end{array}$ & $\begin{array}{l}36 \\
94 \\
20\end{array}$ & 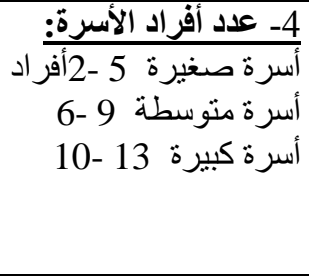 \\
\hline 100 & 150 & المجموع & 100 & 150 & المجموع \\
\hline
\end{tabular}

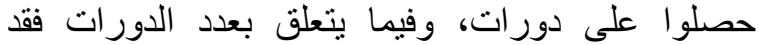

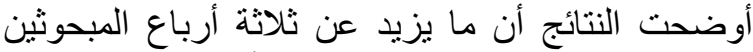

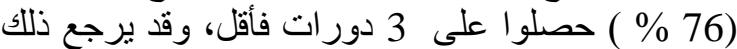

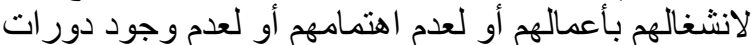

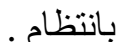
3.5. وصف المتغيرات الخاصة بالجمعيات

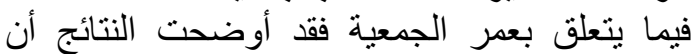

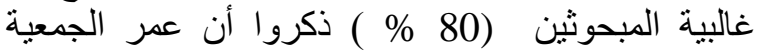
يتر اوح بين 15 و 20 سنة، أما فيما يتعلق مناسبة مبنى

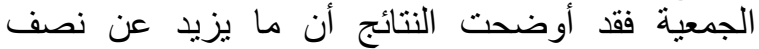
المبحوثين (60 \% م ) ذكروا بأن مبانى الجمعية مناسب،

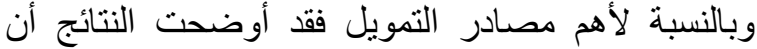
الغالبية العظمى للمبحوثين (92 \% م ) أشناروا إلى أن أهم

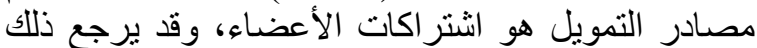

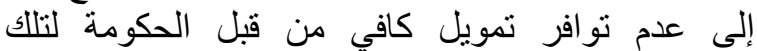

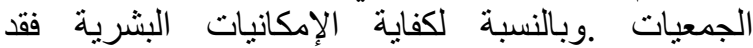

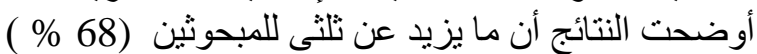

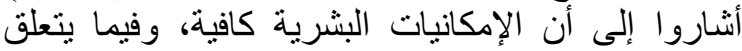
بعلاقة الجمعية بالأجهزة الحكومية فقد أوضحت النتائج أن الن النهان
يملكون مشروع صغنير، وقد يرجع ذلك إلى عدم توافر

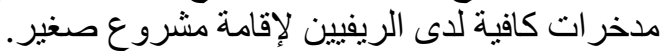
2.5. وصف عينة المبحوثين أعضاء مجلس الإدارة الجمعيات

أوضحت النتائج جدول رقم (6) أن منو ال سن المبحوثين يقع فى الفئة العمرية 54 - 47سنة، وبلغت نسبتهم ( 56\% )، وبالنسبة للحالة الزو اجية للمبحوثين فقد أوضحت النتائج أن الغالبية العظمى من المبحوثين

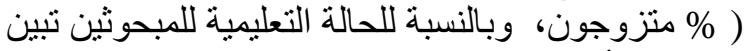
من النتائج أن غالبية المبحوثين ( 88 \% 88 ) في فئة الحالة

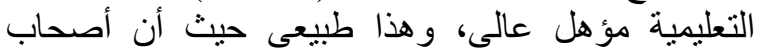

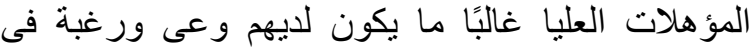
القيادية.

وفيما يتعلق بمهنة المبحوثين فقد أوضحت النتائج أن

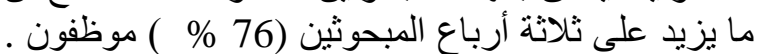

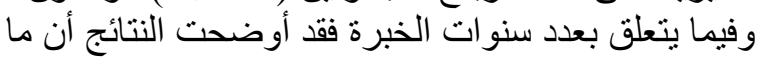
يقرب من نصف المبحوثين ( 48 \%) يقعون في فئئة الخبرة المتوسطة، وقد يرجع ذلك لعدم احتكالك الريفيين

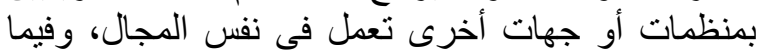

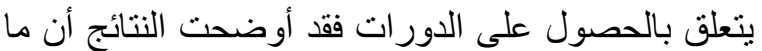
يزيد عن نصف المبحوثين (60 \% ) أشناروا إلى أنهم 


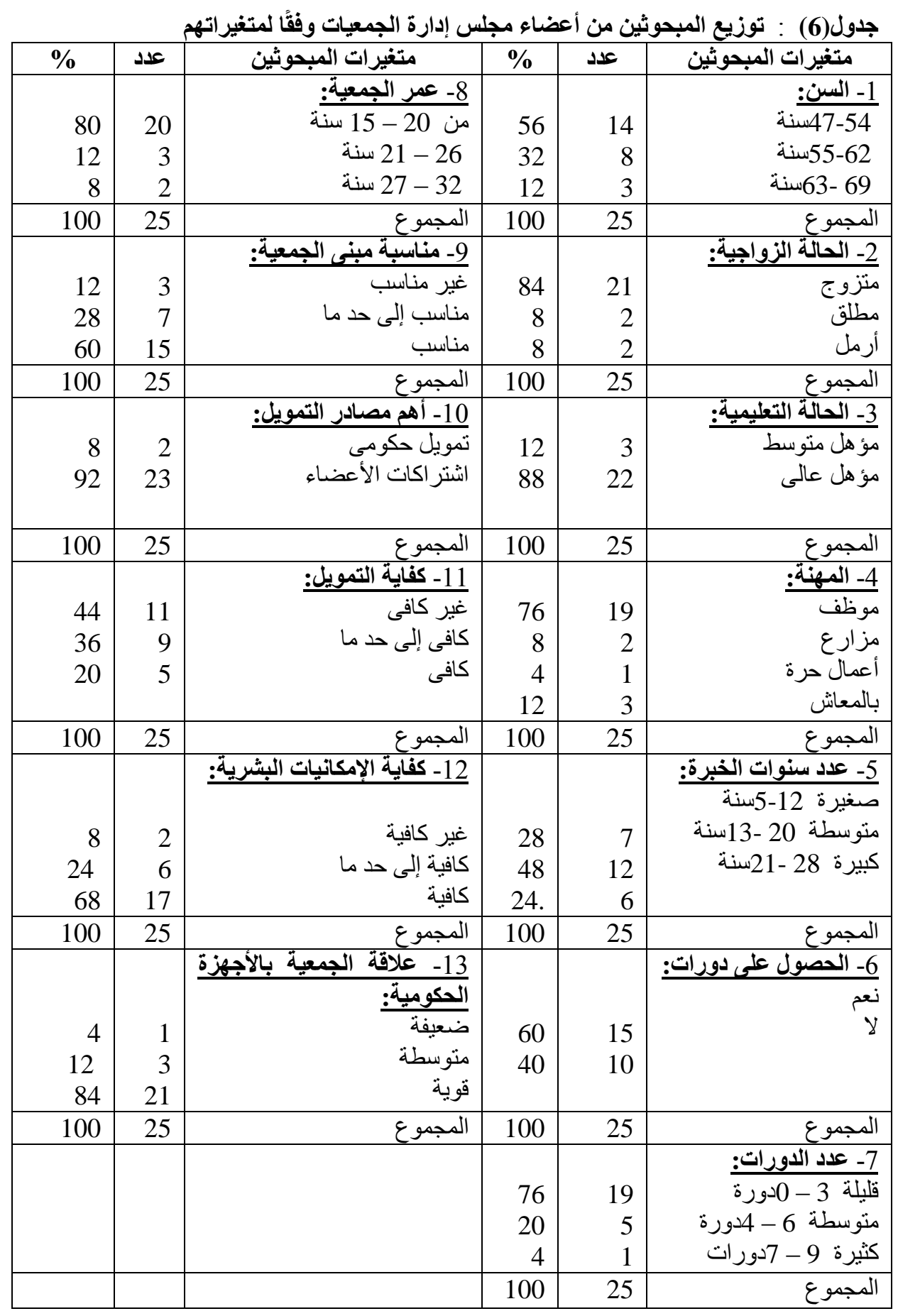

\% ) من المبحوثين مستوى معرفتهم بالأنشطة منوسط،

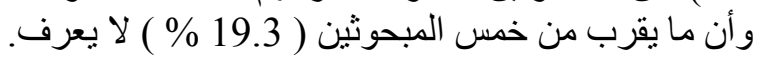

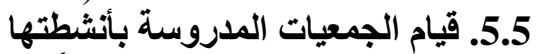

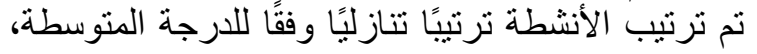

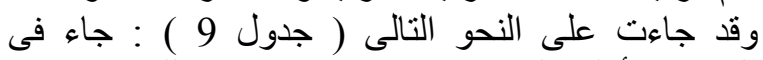

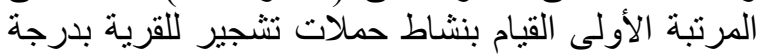

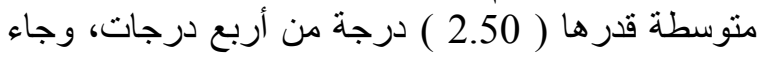

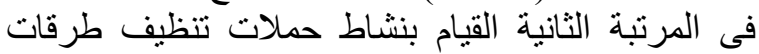

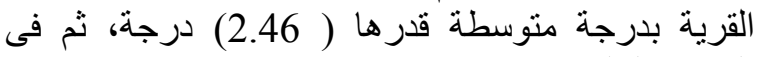

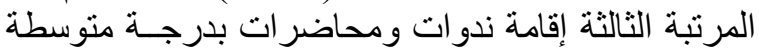

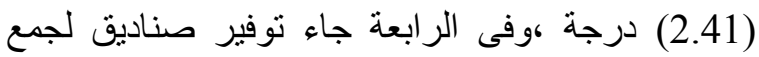
القمامة بدرجة منوسطة قدرجة ها (2.18) درجة وفئ وفى
غالبية للمبحوثين (84 \%) أشاروا إلى أن علاقة الجمعية

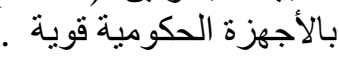
4.5. معرفة المبحوثين المستفيدين من الجمعيات بأنشطتها المدروسة المبنة

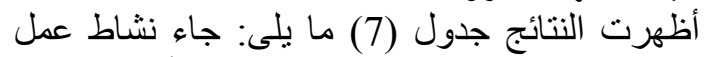

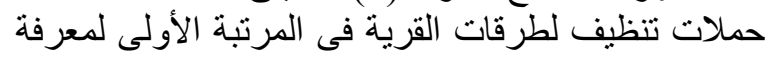

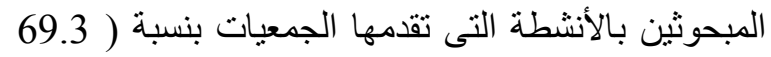
\% ) )، ثم عمل حملات تشجير بالقرية بنسبة ( 64.7 \% \%)،

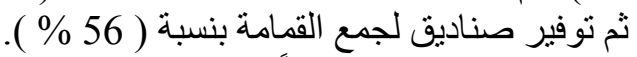

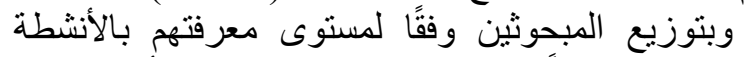
المدروسة إجمالاً تبين من النتائج جدول ( 8 معند ) أن ( 55.4 


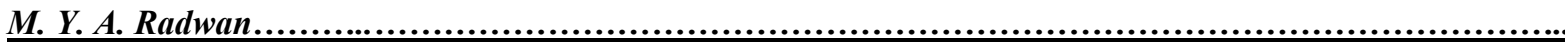

جدول (7): توزيع الريفيين المبحوثين وفقًا لمعرفتهم بأنثطة الجمعيات المدروسة.

\begin{tabular}{|c|c|c|c|c|c|c|}
\hline \multicolumn{2}{|c|}{ الإجمالى - الى } & \multicolumn{2}{|c|}{ ل ل لا يعرف } & \multicolumn{2}{|c|}{ يعرف } & \multirow[t]{2}{*}{ المعرفة } \\
\hline$\%$ & عدد & $\%$ & عدد & $\%$ & عدد & \\
\hline 100 & 150 & 82.6 & 124 & 17.4 & 26 & عمل حصر للمشكلات البيئية الموجودة بالقرية \\
\hline 100 & 150 & 80.7 & 121 & 19.3 & 29 & إعلان الجمعية عن بدأ أنشطتها في مجال البيئة \\
\hline 100 & 150 & 78.7 & 118 & 21.3 & 32 & إقامة دورات تدريبية في مجال البيئة \\
\hline 100 & 150 & 42 & 63 & 58 & 87 & إقامة ندوات ومحاضر ات توعوية بمشكلات البيئية \\
\hline 100 & 150 & 30.7 & 46 & 69.3 & 104 & عمل حملات تنظيف لطرقات القرية \\
\hline 100 & 150 & 35.3 & 53 & 64.7 & 97 & عمل حملات تثجير بالقرية \\
\hline 100 & 150 & 84.7 & 127 & 15.3 & 23 & تنظيم مسابقات فى مجال البيئة \\
\hline 100 & 150 & 88.7 & 133 & 11.3 & 17 & تنظيم رحلات لزيارة المحميات الطبيعية \\
\hline 100 & 150 & 87.3 & 131 & 12.7 & 19 & عمل ملصقات توعوية فى مجال البيئة \\
\hline 100 & 150 & 44 & 66 & 56 & 84 & توفير صناديق لجمع القمامة \\
\hline
\end{tabular}

جدول (8): توزيع الريفيين المبحوثين وفقًا لمستوى

معرفتهم الإجمالية بأنشطة الجمعيات المينوت

\begin{tabular}{|c|c|c|}
\hline$\%$ & عدد & القئـات \\
\hline 19.3 & 29 & لا يعرف \\
\hline 11.3 & 17 & منخفض \\
\hline 55.4 & 83 & متوسط \\
\hline 14 & 21 & مرتفع \\
\hline 100 & 150 & الإجمالى \\
\hline
\end{tabular}

الخامسة عمل ملصقات نوعوية بدرجة متوسطة قدرها

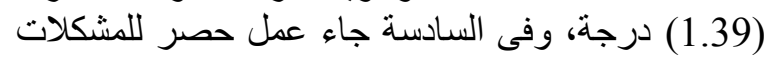

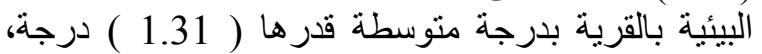
وفى السابعة جاء إعلان الجمعيات عن بدأ نشاطاتها بدرجة النة متوسطة قدرها ( 1.29 ) درجة، داء وفى الثامنة جاء الثاء تنظيم

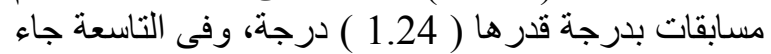

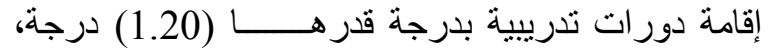
وفى العاثرة جاء تنظيم رحلات للمحميات بدرجة قدر هـات ( )

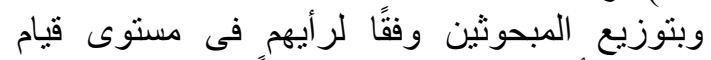
الجمعيات بالأنشطة المدروسة إجمالاً تبين من النتائج النيا جدول (10) أن (42\%) يرونة الن مستوى قيام

جدول (9) : توزيع الريفيين المبحوثين وفقًا لرأيهم في درجة قيام الجمعيات المدروسة بأنشطتها.

\begin{tabular}{|c|c|c|c|c|c|c|c|c|c|c|}
\hline \multirow[t]{2}{*}{ الترتيب } & \multirow{2}{*}{ المتوسطة } & \multicolumn{2}{|c|}{ لا تقوم } & \multicolumn{2}{|c|}{ منخفضة } & \multicolumn{2}{|c|}{ متوسطة } & \multicolumn{2}{|c|}{ مرتفعة } & \multirow{2}{*}{ الأنثطة درجة القيام } \\
\hline & & & & $\%$ & عدد & $\%$ & عدد & $\%$ & عدد & \\
\hline 6 & 1.31 & 82.7 & 124 & 7.3 & 11 & 6 & 9 & 4 & 6 & البيئية الموجر للمشة بكلات \\
\hline 7 & 1.29 & 80.7 & 121 & 10.7 & 16 & 7.3 & 11 & 1.3 & 2 & أنشطتان الجمعية عن البئة \\
\hline 9 & 1.20 & 88.6 & 133 & 4.7 & 7 & 4 & 6 & 2.7 & 4 & إقامة دورات تدرييية فى \\
\hline 3 & 2.41 & 22.6 & 34 & 34 & 51 & 22.7 & 34 & 20.7 & 31 & تو عوية ندوات بمكلات البيئية. \\
\hline 2 & 2.46 & 18.6 & 28 & 22 & 33 & 26.7 & 40 & 32.7 & 49 & القرية حملات تنظيف لطرقات \\
\hline 1 & 2.50 & 27.3 & 41 & 19.3 & 29 & 28.7 & 43 & 24.7 & 37 & عمل حملات تثجير بالقرية \\
\hline 8 & 1.24 & 86 & 129 & 5.3 & 8 & 6.7 & 10 & 2 & 3 & البيئة مسابقات فى مجال \\
\hline 10 & 1.06 & 94.7 & 142 & 4 & 6 & 1.3 & 2 & - & - & النظيميات رحلات لزيارة \\
\hline 5 & 1.39 & 77.4 & 116 & 11.3 & 17 & 6 & 9 & 5.3 & 8 & مجال البيئة ملصقات توعوية فى \\
\hline 4 & 2.18 & 42 & 63 & 2.7 & 4 & 50.6 & 76 & 4.7 & 7 & توفير صناديق لجمع \\
\hline
\end{tabular}


7.5.رضا المبحوثين عن الأنثطة التى تقدمها الجمعيات

$$
\text { المدروسة المنة المبنة }
$$

تم ترتيب الأنشطة ترنيبًا تنازليًا وفقًا للارجة الليّة المتوسطة لرضاهم عن الأنشطة المدروسة، ونارئا وقد جاءت

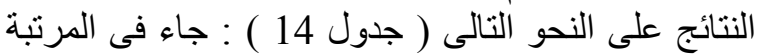

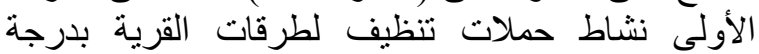

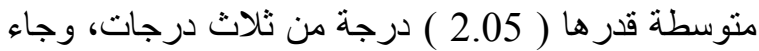

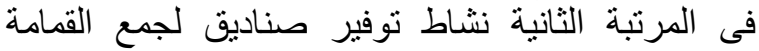

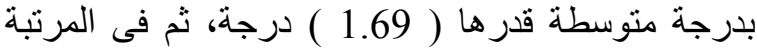

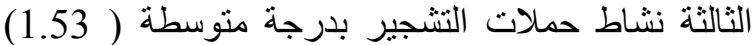

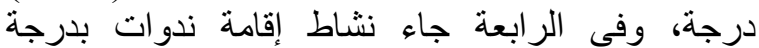
متوسطة قدر ها ( 1.43) درجة، ورجة وفى الخامسة نشاط عمل

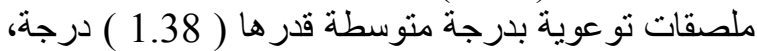
وفى السادسة جاء عمل حصر للمشكلات البيئية بالقرية بدرجة متوسطة قدرها ( 1.33 ) درجة داءة، وفى السابعة جاء

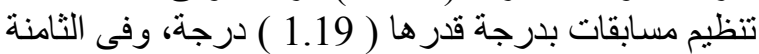

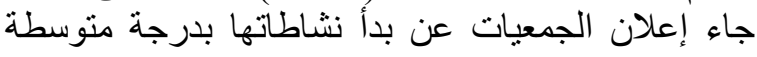

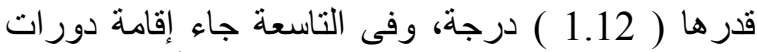

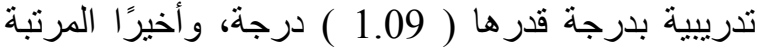

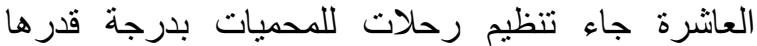

\section{5. العلاقة بين المتغيرات المستقلة المدروسة} للمبحوثين وبين رأيهم في درجة فاعلئية العية الجمعيات

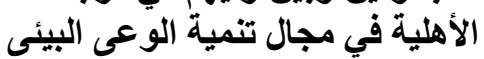

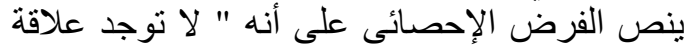

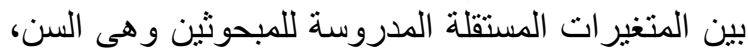
و عدد أفراد الأسرة، والحالة الزواجية الدية، والحالة الحئة التعليمية،

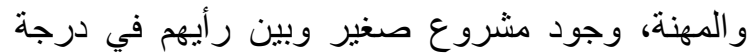
فاعلية الجمعيات الأهلية فيآداء أنشطتها ".

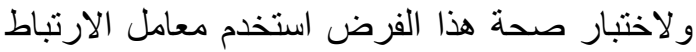

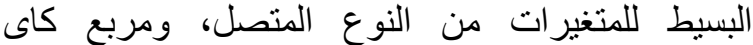

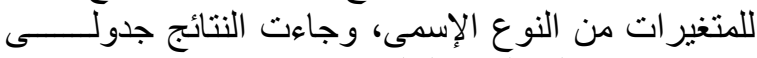

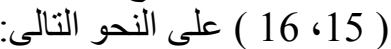

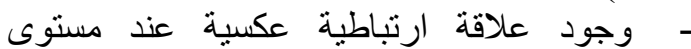

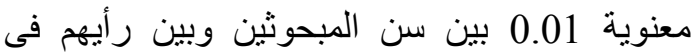

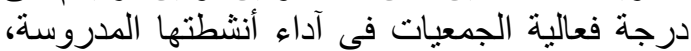

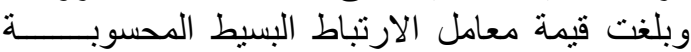
(- 0.146 ) و هى أكبر من نظير الارتياط البها الجدولية.

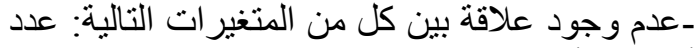
أفراد الأسرة، الحالة الزواجينة الحية، الحالة التعليمية،

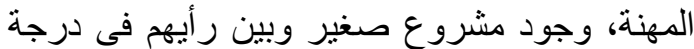

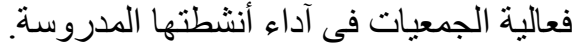

9.5. المشكلات التى تواجه الجمعيات من وجهة نظرة

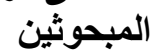

تشير النتائج الواردة بجدول (17) إلى تعدد المشكلات

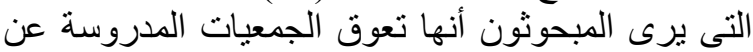

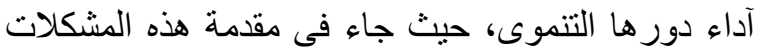

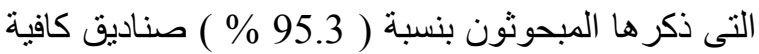

لجمع القمامة بنسبة ( 89.3 \% ) )، ثم عدم عمل حملات
الجمعياتبالأنشطة المدروسة متوسط، وأفاد ما يزيد عن

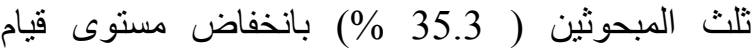
الجمعيات بالأنشطة المدروسة، وكانت أقل نسبة (75.3 \% \%

\begin{tabular}{|c|c|c|}
\hline$\%$ & عدد & الفئات \\
\hline 15.3 & 23 & لا تقوم \\
\hline 35.3 & 53 & منخفض \\
\hline 42 & $\begin{array}{l}63 \\
\end{array}$ & متوسط \\
\hline 7.3 & 11 & مرتفع \\
\hline 100 & 150 & الإجمالى \\
\hline
\end{tabular}
منهم ترى ارتفاع مستوى قيام الجمعيات بالأنشطة.

6.5.استفادة المبحوثين من أنشطة الجمعيات المدروسة

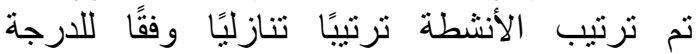

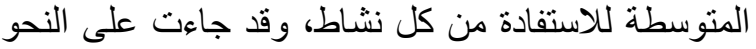
التالى ( جدول 11 ) : جاء فئ في المرنبة الأولى القيام بنشاط

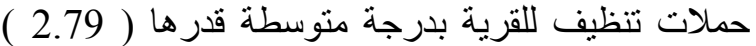
درجة من أربع درجات، وجاء فئ المرنبة الثانية القيام

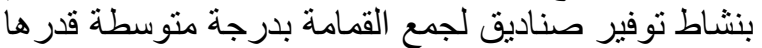

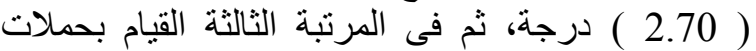
تشجير بدرجة منوسطة ( 2.66 ) درجة، دورة وفى الر ابعة جاء

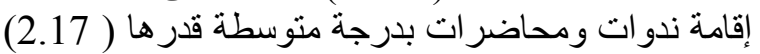

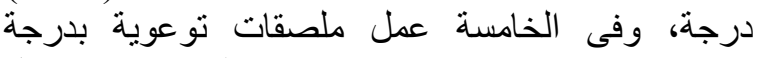

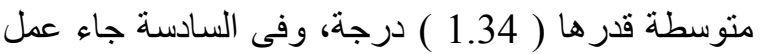

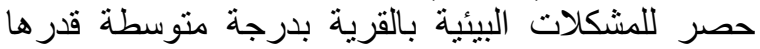

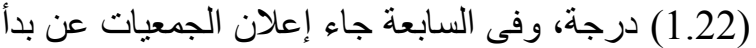

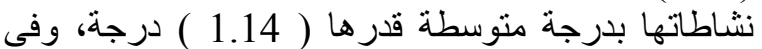

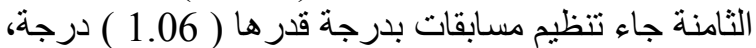

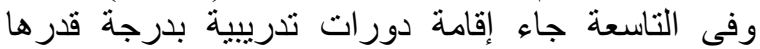

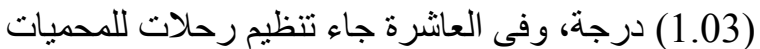
بدرجة قدر ها ( 1.02 ) درجة درجة. وبتوزيع المبحوثين وفقًا لمستوى استفادتهم الإجمالية

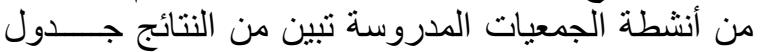

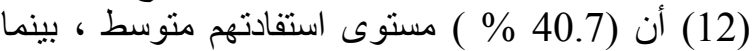
أفاد ( 36 \% \% ) بانخفاض مستوى استفادتهم، وكانت أقل نسبة ( 5.3 \% \%) منهم مستوى استفادتهم مرتفع.

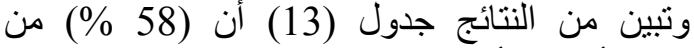
المبحوثين أفادوا بأن مستوى فعالية الجمعيات فى آلئ آداء

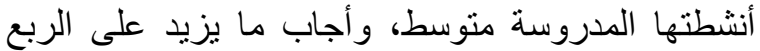
بقليل ( 26.7 \% ) بانخفاض مستوى فعالية الجمعيات فيى الجئ

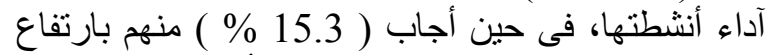

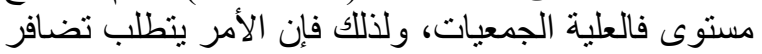

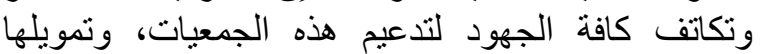
بالثكل الذى يجعلها أكثر قدرة على تلى تحقيق أهدافها و القيام

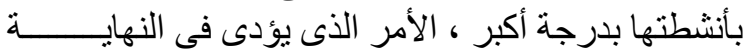
إلى زيادة فعاليتها فى خدمة الريف و أهله. 
جدول (11) : توزيع الريفيين المبحوثين وفقًا لارجة استفادتهم من أنثطة الجمعيات .

\begin{tabular}{|c|c|c|c|c|c|c|c|c|c|c|}
\hline \multirow[t]{2}{*}{ الترتيب } & \multirow{2}{*}{ المتوسطة } & \multicolumn{2}{|c|}{ لا توجد استفادة } & \multicolumn{2}{|c|}{ منخفضة } & \multicolumn{2}{|c|}{ متوسطة } & \multicolumn{2}{|c|}{ مرتفعة } & \multirow{2}{*}{ الأنشطة درجة الاستفادة } \\
\hline & & $\%$ & عدد & $\%$ & عدد & $\%$ & عدد & $\%$ & عدد & \\
\hline 6 & 1.22 & 89.3 & 134 & 2 & 3 & 5.3 & 8 & 3.3 & 5 & الموجل حصدة بالمرية \\
\hline 7 & 1.14 & 93.3 & 140 & 1.3 & 2 & 3.3 & 5 & 2 & 3 & 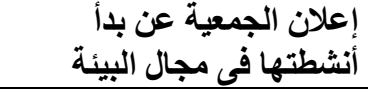 \\
\hline 9 & 1.03 & 96.7 & 145 & 3.3 & 5 & - & - & - & - & إقامة دورات تدريبية \\
\hline 4 & 2.17 & 42 & 63 & 2.7 & 4 & 51.3 & 77 & 4 & 6 & تإقاموية ندوات ومحاضر ات \\
\hline 1 & 2.79 & 8.7 & 13 & 22.6 & 34 & 49.4 & 74 & 19.3 & 29 & عمل حملات تنظيف الطرقات \\
\hline 3 & 2.66 & 18.6 & 28 & 16.7 & 25 & 44.7 & 67 & 20 & 30 & عمل حملات تثجير بالقرية \\
\hline 8 & 1.06 & 95.3 & 143 & 2.7 & 4 & 2 & 3 & - & - & تنظئيم مسابقات فى مجال \\
\hline 10 & 1.02 & 97.3 & 146 & 2.7 & 4 & - & - & - & - & الطبيعية رحلات للمحميات \\
\hline 5 & 1.34 & 76.7 & 115 & 6.7 & 10 & 6.7 & 10 & 6 & 9 & عمل ملصقات توعوية \\
\hline 2 & 2.70 & 11.3 & 17 & 27.3 & 41 & 40.7 & 61 & 20.7 & 31 & صناديق القمامة \\
\hline
\end{tabular}

جدول (13) : توزيع الريفيين المبحوثين وفقًا لرأيهم فى مستوى فعالية الجمعيات في آداء أنشطتها.

\begin{tabular}{|c|c|c|c|c|c|c|c|c|}
\hline \multicolumn{2}{|c|}{ الإجمالى } & \multicolumn{2}{|c|}{ منخفضة } & \multicolumn{2}{|c|}{ متوسطة } & \multicolumn{2}{|c|}{ مرتفعة } & \multirow{2}{*}{ الفعاليةتوى } \\
\hline$\%$ & عدد & $\%$ & عدد & $\%$ & عدد & $\%$ & عدد & \\
\hline 100 & 150 & 26.7 & 40 & 58 & 87 & 15.3 & 23 & إجمالاً \\
\hline
\end{tabular}

جدول (12): توزيع الريفيين المبحوثين وفقًا

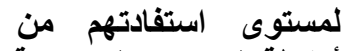

أنثطة الجمعيات المدروسة.

\begin{tabular}{|c|c|c|}
\hline$\%$ & عدد & الفئات \\
\hline 18 & 27 & لا توجد استفادة \\
\hline 36 & 54 & استفادة منذفضة \\
\hline 40.7 & 61 & استفادة متوسطة \\
\hline 5.3 & 8 & استفادة مرتفعة \\
\hline 100 & 150 & الإجمالى \\
\hline
\end{tabular}

جدول(14) : توزيع الريفيين المبحوثين وفقًا لارجة رضاهم عن أنثطة الجمعيات

\begin{tabular}{|c|c|c|c|c|c|c|c|c|}
\hline \multirow[t]{2}{*}{ الترتيب } & \multirow{2}{*}{ المتوسطة } & \multicolumn{2}{|c|}{ 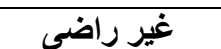 } & \multicolumn{2}{|c|}{ 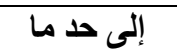 } & \multicolumn{2}{|c|}{ راضى } & \multirow[t]{2}{*}{ درجة الرضى } \\
\hline & & $\%$ & عدد & $\%$ & عدد & $\%$ & عدد & \\
\hline 6 & 1.33 & 73.3 & 110 & 20 & 30 & 6.7 & 10 & بالقربة حصر للمشكلات البيئية الموجودة \\
\hline 8 & 1.12 & 84.6 & 127 & 11.3 & 17 & 4 & 6 & إعلان الجمعية عن بدأ أنثطتها فى \\
\hline 9 & 1.09 & 92.6 & 139 & 5.3 & 8 & 2 & 3 & إقامةة دورات تدرييية في مجال البيئة \\
\hline 4 & 1.43 & 61.3 & 92 & 34 & 51 & 4.7 & 7 & بمشكلات البيئية. \\
\hline 1 & 2.05 & 32.7 & 49 & 29.3 & 44 & 38 & 57 & عمل حملات تنظيف لطرقات القرية \\
\hline 3 & 1.53 & 52.7 & 79 & 41.3 & 62 & 6 & 9 & عمل حملات تثجير بالقرية \\
\hline 7 & 1.19 & 88.7 & 133 & 3.3 & 5 & 8 & 12 & تنظيم مسابقات فى مجال البيئة \\
\hline 10 & 1.06 & 96 & 144 & 1.3 & 2 & 2.7 & 4 & تنظيم رحلات لزيارة المحميات الطبيعية \\
\hline 5 & 1.38 & 65.3 & 98 & 30.7 & 46 & 4 & 6 & عمل ملصقات توعوية في مجال البيئة \\
\hline 2 & 1.69 & 45.3 & 68 & 40 & 60 & 14.7 & 22 & توفير صناديق لجمع القمامة \\
\hline
\end{tabular}


جلول (16) : قيم اختبار مريع كاى بين كلا من المتغيرات المستقلة المدروسة للمبحوثين وبين رأيهم فى درجة المئين فاعلية

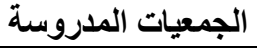

\begin{tabular}{|c|c|c|c|c|}
\hline صشروع صغود & المهنة & التعليمية الحالة & الزوالة الزية & المستختيرات \\
\hline 5.911 & 12.762 & 6.243 & 6.400 & قيم مربع كاى \\
\hline
\end{tabular}

جدول (15) : قيم معامل الارتباط البسيط بين كلا من

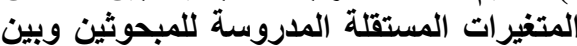

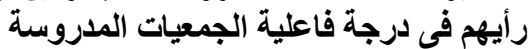

\begin{tabular}{|c|c|c|}
\hline عدد أفراد & 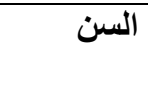 & المتغيرات المستقلة \\
\hline-0.079 & $-0.146 *$ & قيم معامل الارتباط البسيط \\
\hline
\end{tabular}

0.05 * معنوية عند مستوى 0.01 * معنوية عند مستوى

جدول (17) : المشكلات التى تواجه الجمعيات المدروسة من وجهة نظر المستفيدين

\begin{tabular}{|c|c|c|c|c|}
\hline الترتيب & $\%$ & 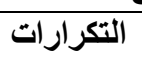 & المشكلات & s \\
\hline 1 & 95.3 & 143 & وموا وجود نشرات أو مجلات دورية لتعريف الموطنين بنشاطات الجمعية & 1 \\
\hline 4 & 61.3 & 92 & عدم إقامة دورات تلدريبية & 2 \\
\hline 5 & 52.7 & 79 & عدم إقامة ندوات ومحاضرات توعوية بالمشكلات البيئية & 3 \\
\hline 3 & 76.7 & 115 & عدم عمل حملات تتظيف لطرقات القرية باستمرار & 4 \\
\hline 6 & 45.3 & 68 & عدم عمل حملات تشجير بالقرية باستمرار & 5 \\
\hline 8 & 34 & 51 & عدم تنظيم مسابقات فى مجال البيئة & 6 \\
\hline 9 & 30.7 & 46 & عدم تتظيم رحلات لزيارة المحميات الطبيعية & 7 \\
\hline 7 & 40 & 60 & عدم عمل ملصقات توعوية فى مجال البيئة & 8 \\
\hline 2 & 89.3 & 134 & عدم توفير صناديق كافية لجمع القمامة & 9 \\
\hline
\end{tabular}

جدول (18) : مقترحات المبحوثين الريفيين للتظلب على المشكلات التى تواجه الجمعيات المدروسة

\begin{tabular}{|c|c|c|c|c|}
\hline الترتيب & $\%$ & 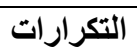 & 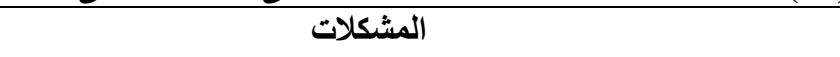 & b \\
\hline 1 & 92.7 & 139 & عمل نشرات أو مجلات دورية للتعريف بنشاطات الجمعية ومواعيدها & 1 \\
\hline 4 & 58.7 & 88 & إقامة دورات تلريبية & 2 \\
\hline 5 & 44.6 & 67 & إقامة ندوات ومحاضرات توعوية بالمشكلات البيئية & 3 \\
\hline 3 & 78 & 117 & عمل حملات تتظيف لطرقات القرية باستمرار & 4 \\
\hline 6 & 40.7 & 61 & عمل حملات تثجير بالقرية باستمرار & 5 \\
\hline 8 & 31.3 & 47 & تنظيم مسابقات فى مجال البيئة & 6 \\
\hline 9 & 26.6 & 40 & تنظيم رحلات لزيارة المحميات الطبيعية & 7 \\
\hline 7 & 36 & 54 & عمل ملصقات توعوية فى مجال البيئة & 8 \\
\hline 2 & 87.3 & 131 & توفير صناديق كافية لجمع القمامة & 9 \\
\hline
\end{tabular}


و أخيرًا ضعف الدعم الفنى بنسبة ( 56 \% ) ).

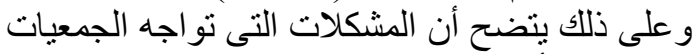

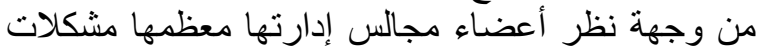

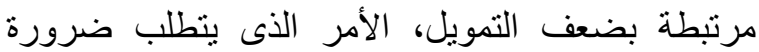

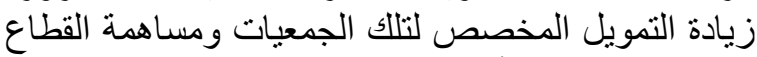

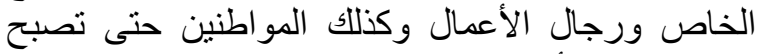
فعالة وتحقق الأدوار التنموية المنشودة منها. 12.5. مقترحات التفلب على المشكلات التى التى تواجها. الجمعيات من وجهة نظر أعضاء مجلس الإلادرة

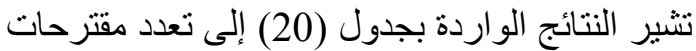

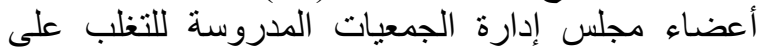

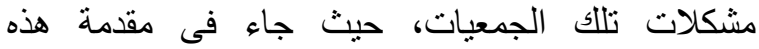
المقترحات التى ذكرها المبحوثون بنسبة ( 100\%) فئاء

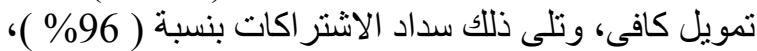

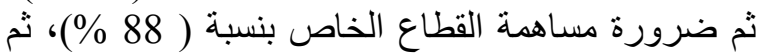

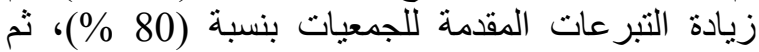
تيسير إنهاء الإجراءات التيرة الخاصة مع الجهات التهات الحكومية بنسبة (76 \% \% )، ثم إقامة دور ات تدريبية الإدية للأعضاء بنسبة

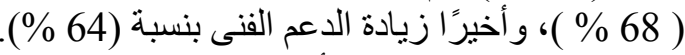

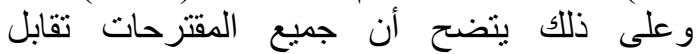
المشكلات التى ذكرها أعضاء مجالس إدار العات الجمعيات

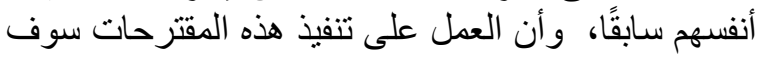

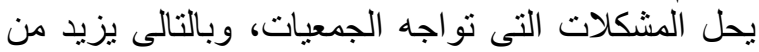
فعاليتها فى آداء دور ها التنموى.

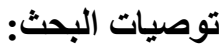

1-نظرًا لما أظهرته النتائج من ضعف الإمكان النهانيات المادية

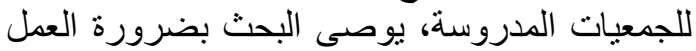

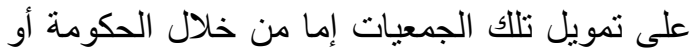

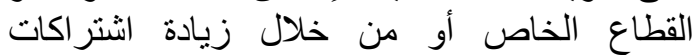
الأعضاء، أو من خلال زيادة المشروعات الفيات المدرة

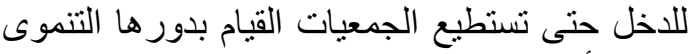
وتحقق أهدافها.

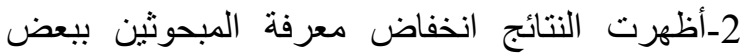

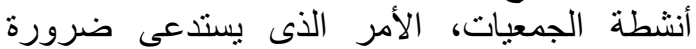
الإعلان عن الأنشطة المختلفة للجمعيات لتعظيم المعرفة و الاستفادة منها.

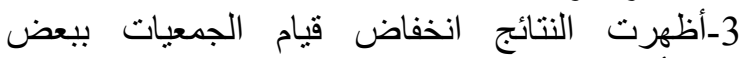
الأنشطة مما يستلزم إحكام الرقابة و المتابعة على الرئل هذه

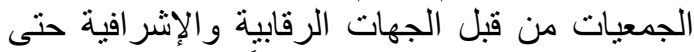
يتسنى لها القيام بهذه الأنشطة تحقيقًا لأهداف الهـا. 4-أظهرت النتائج انخفاض استفاد الأنادة المبحوثين من أنشطة

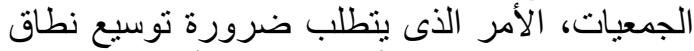
عمل الجمعية ليستو عب أكبر نسبة من أفراد الفير المجنمع.

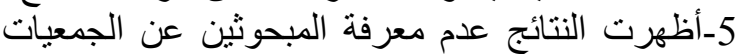

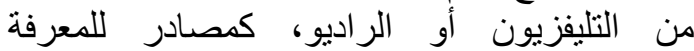

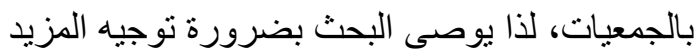

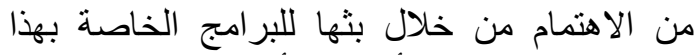
النوع من الجمعيات، و أهدافها و أنشطنها.
لجمع القمامة بنسبة ( 89.3 \% ) )، ثم عدم عمل حملات

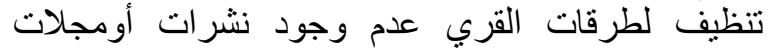
دورية لتعريف المواطنين بنشاطات الجمعية ومو اعيدها،

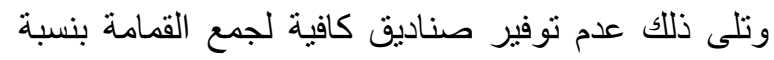

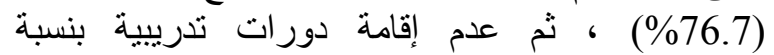

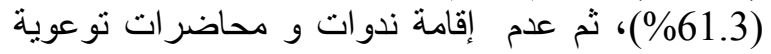

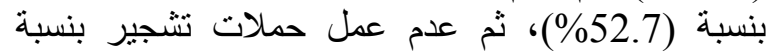

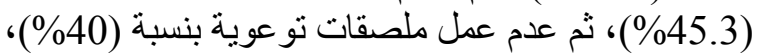

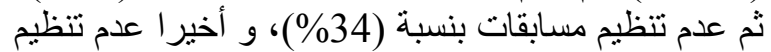
رحلات للمحميات الطبيعية بنسبة (30.7\%) و على ذللك يتضح أن المشكلات التى نو اجه الجهات الجمعيات

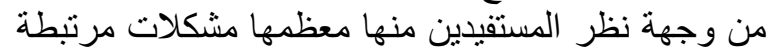

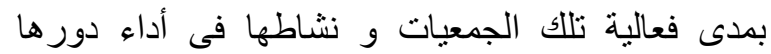

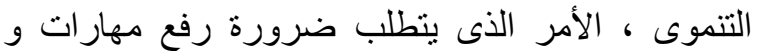

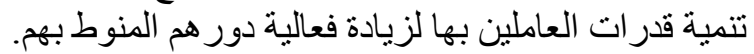

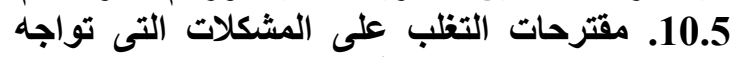
الجمعيات من وجهة نظر المبحوثين

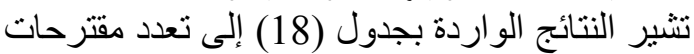

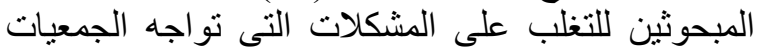

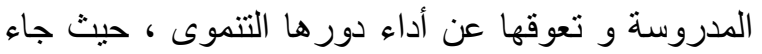
فى مقدمة هذه المقترحات التى ذكرها التها المبحوثين بنسبة

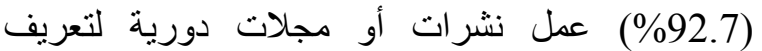
المواطنين بنشاطات الجمعية و مواعيدها، و و تلى ذلى ذلك

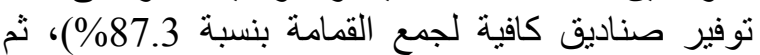
عمل حملات تنظيف لطرقات القرية القرية بإستمرار بنسبة

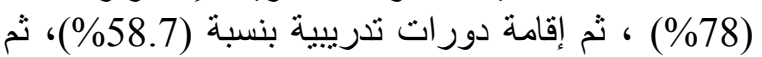

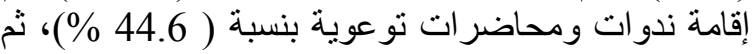
عمل حملات تشجير بنسبة (40.7 \% \%)، ثم عمل ملصقات

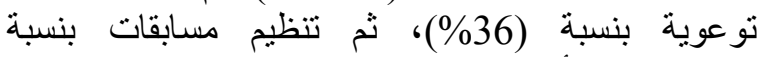
(31.3\%)، وأخيرًا تنظيم رحلات للمحميات الطبيعية

بنسبة ( 26.6 \%).

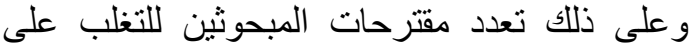

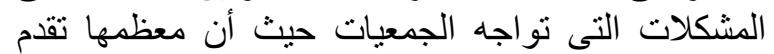

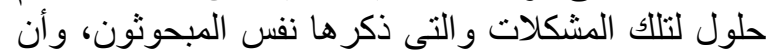

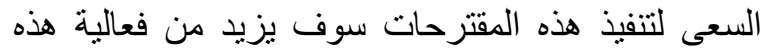

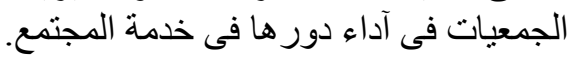

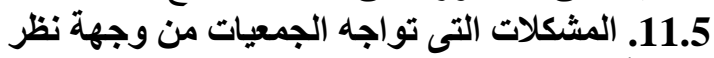
أعضاء مجلس الإدارة

تشير النتائج الواردة بجدول الإدارة (19) إلى تعدد المشكلات

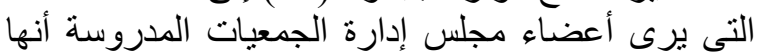

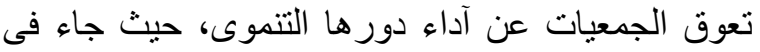

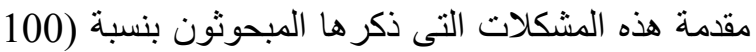

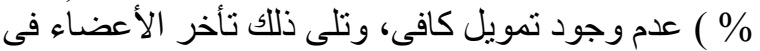

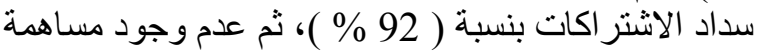

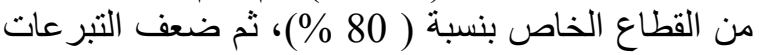

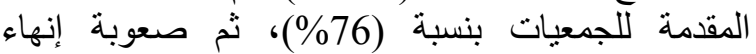

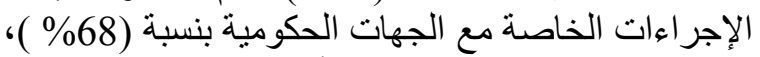

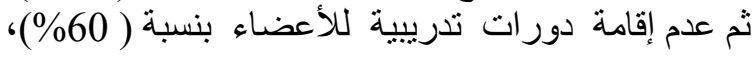


جدول (19) : المشكلات التي تواجه الجمعيات المدروسة من وجهة نظر أعضاء مجلس الإدارة

\begin{tabular}{|c|c|c|c|c|}
\hline الترتيب & $\%$ & التكرارات & المشكلات & b \\
\hline 1 & 100 & 25 & عدم وجود تمويل كافي للجمعية & 1 \\
\hline 3 & 80 & 20 & عدم وجود مساهمة مالية من القطاع الخاص للجمعية & 2 \\
\hline 2 & 92 & 23 & تأخر الأعضاء فى سداد الاشتراكات & 3 \\
\hline 4 & 76 & 19 & ضعف التبرعات التى يقدمها المواطنون للجمعية & 4 \\
\hline 7 & 56 & 14 & ضعف الدعم الفنى المقدم من وزارة البيئة & 5 \\
\hline 6 & 60 & 15 & عدم إقامة دورات تدريبية للأعضاء & 6 \\
\hline 5 & 68 & 17 & صعوبة إنهاء الإجراعات الخاصة بالجمعية مع الجهات الحكومية & 7 \\
\hline
\end{tabular}

جدول (20) : مقترحات أعضاء مجلس إدارة الجمعيات المدروسة للتظلب على المشكلات التى تواجهها

\begin{tabular}{|c|c|c|c|c|}
\hline الترتيب & $\%$ & 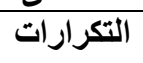 & 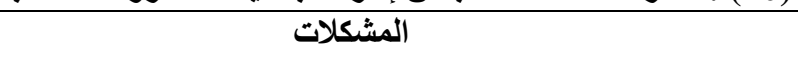 & b \\
\hline 1 & 100 & 25 & توفير تمويل كافي للجمعية & 1 \\
\hline 3 & 88 & 22 & مساهمة القطاع الخاص المالية للجمعية & 2 \\
\hline 2 & 96 & 24 & سداد الأعضاء الاشتراكات & 3 \\
\hline 4 & 80 & 20 & توفير أموال عن طريق التبرعات التى يقدمها المواطنون للجمعية & 4 \\
\hline 7 & 64 & 16 & زيادة الاعم الفنى المقدم من وزارة البيئة & 5 \\
\hline 6 & 68 & 17 & إقامة دورات تلريبية للأعضاء & 6 \\
\hline 5 & 76 & 19 & تيسير إنهاء الإجراءات الخاصة بالجمعية مع الجهات الحكومية & 7 \\
\hline
\end{tabular}

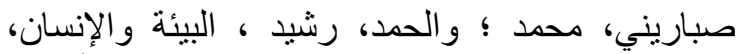

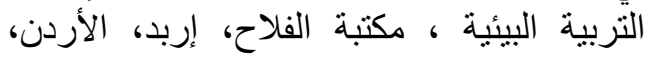

. 1994

عبد اللطيف، رشاد احمد، مهار ات الخدمة الاجتماعية في

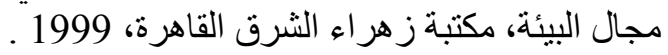

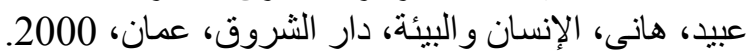

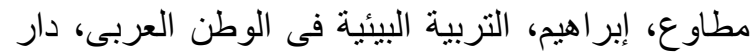

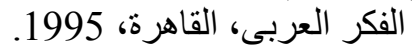

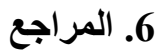

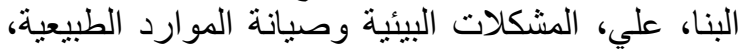

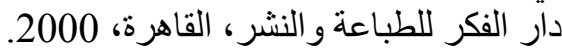

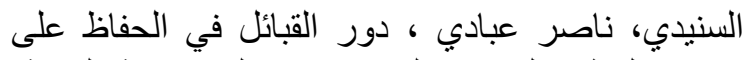
الغطاء النباتي و المر اعي في الجمهورية اليمنية، دورية الئية من وقائع وأبحاث المؤتمر العي العي التي الأول للبيئة و الموارد الطبيعية، 22 أبريل، 2000.

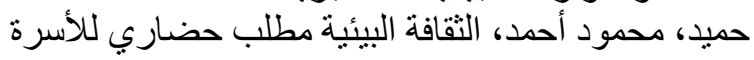
، دار الرضا للنشر ، دمشق، شحاته، حسن احمد، البيئة والمشكلة السكانية، عربية دانية للطباعة و النشر، القاهرة، الهدة 2001. 